\title{
The impact of hyperthermic chemotherapy on human gastric cancer cell lines: Preliminary results
}

\author{
RUI TANG, ZHENG GANG ZHU, YING QU, JIAN FANG LI, YU BAO JI, QU CAI, \\ BING YA LIU, MIN YAN, HAO RAN YIN and YAN ZHEN LIN \\ Department of General Surgery, Shanghai Institute of Digestive Surgery, RuiJin Hospital, \\ School of Medicine, Shanghai Jiaotong University, Shanghai, China
}

Received February 27, 2006; Accepted May 22, 2006

\begin{abstract}
In this preliminary study, we evaluated the impact of hyperthermia (HT) and hyperthermic chemotherapy (HTCT) on six human gastric cancer cell lines and explored the mechanisms of cell-killing effect under HTCT. Treatment conditions were categorized into 4 modes: i) normothermic control (NT), ii) HT, iii) normothermic chemotherapy (NTCT) and iv) HTCT. According to the data of MTT and LM observations, isolated HT only temporarily inhibited cell proliferation and had no cell-killing effect on gastric cancer cell lines employed in our study except for SNU-1. Combining with HT enhanced the cytotoxicity of CDDP in all gastric cell lines and the concentration inhibiting cell proliferation and inducing cell death of HTCT was much lower than that of NTCT. There was a synergistic effect of HT and chemotherapy on inhibiting proliferation in each cell line in a certain range of CDDP concentration. The data of TEM and FCM proved that HTCT induced cell death with two modes apoptosis and necrosis, and apoptosis was the major type. Microarray illustrated that, under HTCT, a total of 58 gene expressions were regulated according to the filtering criteria, including 10 extra genes with an expression change below the threshold or even unchanged when treated with either HT or CDDP alone. Five of these 10 genes were verified by
\end{abstract}

Correspondence to: Professor Zheng Gang Zhu, Shanghai Institute of Digestive Surgery, RuiJin Hospital, No. 197 RuiJin Er Road, 200025 Shanghai, China

E-mail: zzg1954@hotmail.com; kevintown2002@hotmail.com

Abbreviations: HTCT, hyperthermic chemotherapy; NT, normothermia or normothermic; HT, hyperthermia; NTCT, normothermic chemotherapy; N87, NCI-N87; CDDP, Cisdiamminedichloroplatinum; IPHC, intraperitoneal hyperthermic chemotherapy; MTT, 3-[4,5-dimethythiazol-2-yl]-2,5-diphenyltetrazoliumbromode; A value, absorbance value; LM, light microscopy; TEM, transmission electron microscopy; FCM, flow cytometry; FITC, fluorescein isothiocyanate; PI, propidium iodide; QRT-PCR, quantitative real-time polymerase chain reaction; GAPDH, glyceraldehyde-3-phosphate dehydrogenase

Key words: gastric cancer, cell lines, hyperthermic chemotherapy, cell proliferation, cell-killing effect, apoptosis, necrosis
QRT-PCR. These genes may include the target genes for the enhancing effect of HT on chemotherapy and their effects should be further validated by functional analysis.

\section{Introduction}

Thermotherapy is one of the oldest methods in the history of cancer treatment. Modern medicine has proved that hyperthemia is effective for certain malignancies. Clinically, 'hyperthemia' refers to various techniques of heat application administered in the treatment of cancer patients. Usually, hyperthermia is applied as an adjunct to chemotherapy and radiotherapy, enhancing the cell-killing effect of cytotoxic drugs and radiation. Its effect has been demonstrated in clinical trials and experimental studies for many neoplasms, including melanoma, osteosarcoma, glioblastoma, breast cancer, cervical cancer, oesophagus cancer, rectal cancer and prostate cancer (1-4).

Gastric cancer is one of the most frequent malignancies in the Far East. Peritoneal dissemination is the major cause of postoperative recurrence and cancer death for gastric cancer patients. Routine systemic chemotherapy is inefficient for both the prevention and treatment of peritoneal dissemination due to the existence of the peritoneal-plasma barrier. Intraperitoneal hyperthermic chemotherapy (IPHC) has also been introduced; improved response and survival rate were observed in some prospective randomized control trials (5-8). However, different from systemic chemotherapy, IPHC is a time-limited modality with relatively high-dose of anticancer drugs. There is little information on the definite mechanism of IPHC on peritoneal dissemination and the impact of hyperthemia (HT) and hyperthermic chemotherapy (HTCT) on gastric cancer cell. Thus, in this preliminary study, we simulated some conditions of IPHC in vitro to investigate the impact of HT and HTCT on gastric cancer by using several human gastric cancer cell lines.

\section{Materials and methods}

Cell lines and culture conditions. Six gastric cancer cell lines, AGS (ATCC no. CRL-1739), MKN45, SGC-7901, NCI-N87 (CRL-5822), SNU-1 (CRL-5971), SNU-16 (CRL-5974) were used in this study (Table I). Cells were cultured using RPMI-1640 medium (Gibco BRL, Life Technologies Inc., USA) containing $10 \%$ fetal bovine serum, $100 \mathrm{U} / \mathrm{ml}$ penicillin/ 
Table I. Features of six human gastric cancer cell lines.

Cell line Origin, differentiation and growth pattern

AGS Female; Caucasian; poorly differentiated adenocarcinoma, stomach; adherent

MKN45 Female; Asian; poorly differentiated adenocarcinoma (medullary type), stomach; adherent

SGC-7901 Female; Asian; lymph node metastasis of a moderately differentiated adenocarcinoma; adherent

N87 Male; Asian; liver metastasis of a well differentiated carcinoma; adherent

SNU-1 Male; Asian; a poorly differentiated primary carcinoma; suspension, multicell aggregates

SNU-16 Female; Asian; of a patient with poorly differentiated carcinoma, ascites; suspension, multicell aggregates

streptomycin and $20 \mathrm{mM}$ HEPES buffer at $37^{\circ} \mathrm{C}$ in a humidified incubator under $5 \% \mathrm{CO}_{2}$ and $95 \%$ air atmosphere. Cells were used for experiments when they were in the exponential growth phase.

Treatment conditions. In this study, the treatment conditions were categorized into 4 modes: NT, HT, NTCT and HTCT. HTCT simulated those of IPHC but in vitro.

HT and NT. HT was achieved by incubating cells at $43^{\circ} \mathrm{C} \pm 0.1^{\circ} \mathrm{C}$ in another humidified $\mathrm{CO}_{2}$ incubator for $2 \mathrm{~h}$. After that, cells were returned to $37^{\circ} \mathrm{C}$ in $\mathrm{CO}_{2}$ incubator for further culture. Cells maintained at $37^{\circ} \mathrm{C}$ in $\mathrm{CO}_{2}$ incubator without chemotherapy served as NT control.

Chemotherapy. CDDP was purchased from QiLu Pharmaceutical Inc. (China). Drug administration was performed by replacing normal media with $\mathrm{CDDP}$-containing media in various concentrations ranging from $0.25 \mu \mathrm{g} / \mathrm{ml}$ to $32 \mu \mathrm{g} / \mathrm{ml}$ in the $\mathrm{CO}_{2}$ incubator for $2 \mathrm{~h}$, after which the therapeutic media were replaced with normal media and then further incubated routinely.

NTCT and HTCT. Chemotherapy performed at $37^{\circ} \mathrm{C}$ was defined as NTCT. HTCT was achieved when two approaches, HT and chemotherapy, were combined by replacing CDDP containing media and cultured at $43^{\circ} \mathrm{C}$ for $2 \mathrm{~h}$.

For adherent cell lines, cells were seeded into culture flasks or well-plates at an appropriate density and allowed to settle for at least $24 \mathrm{~h}$ before treatment. For suspension cell lines, cells were collected in $1.5 \mathrm{ml}$ Eppendorf tubes before treatment and returned to culture flasks or well-plates for further normal culture after treatment.

MTT assay. MTT assay was adopted to evaluate cell proliferation and cytotoxicity after different treatment conditions. For adherent cell lines, $24 \mathrm{~h}$ before treatment, single-cell suspensions were obtained by trypsination of the monolayer cell cultures. Cell counts were performed using a hemocytometer and 1000 to 2000 cells in $200 \mu \mathrm{l}$ media were seeded into 96-well plates. (the cell number was equal for each cell line but unequal for various cell lines due to the different proliferation ability of the cell lines.) After treatment, plates were returned to normal conditions and cells were further cultured. For the suspension cell lines, single-cell suspensions were collected in 1.5-ml Eppendorf tubes, each containing $5 \times 10^{5}$ cells in $1 \mathrm{ml}$ media with or without CDDP. After treatment, 4000 cells were seeded into 96-well plates and each well was further culture. Medium (200 $\mu \mathrm{l})$ without cells served as background control.

At 24, 48, 72, 96 and $120 \mathrm{~h}$ after treatment, $20 \mu \mathrm{l}$ MTT (Sigma, USA) of $5 \mathrm{mg} / \mathrm{ml}$ was added to each well and cells were incubated at $37^{\circ} \mathrm{C}$ for an additional $4 \mathrm{~h}$. After centrifugation, the supernatant was carefully aspirated and $150 \mu 1$ DMSO (Sigma) was added to each well. Immediately after resolubilization, all plates were scanned at $570 \mathrm{~nm}$ on a multi-well spectrophotometer ( $\mu$ Quant, BioTec Instruments, USA). The blanked absorbance (A) value represented the amount of live cells. Each drug concentration and temperature combination was performed quintuplicate or sextuple and all experiments were repeated 3-4 times.

The growth curve was plotted using A value. To determine the cytotoxicity of each drug concentration and temperature combination, the A value ratio of $72 \mathrm{~h}$ after treatment was calculated according to the following equation: $\mathrm{T} / \mathrm{Cx} 100 \%$, where $\mathrm{T}$ is the A value of experimental wells and $\mathrm{C}$ is that of NT control wells. The mean and standard deviations of ratio were reported based on 3-4 independent experiments.

Light microscopy. The proliferation, viability and morphological changes of cells after different treatments were dynamically observed by light microscopy. Treatment was similar to that of MTT, except that 20,000 to 40,000 cells in $2 \mathrm{ml}$ media were seeded into 6-well plates. At 24, 48, 72, 96 and $120 \mathrm{~h}$ after treatment, plates were observed under converse phase-contrast microscopy (Olympus, IX70) and images were taken with a digital camera.

Transmission electron microscopy (TEM). TEM was adopted in this study to further observe the definite death-type after HT, NTCT and HTCT on AGS and SNU-1. CDDP concentrations were $0,1 \mu \mathrm{g} / \mathrm{ml}$ and $4 \mu \mathrm{g} / \mathrm{ml}$. After collection, specimens were fixed with $2 \%$ glutaraldehyde in $0.1 \mathrm{M}$ PBS for $2 \mathrm{~h}$ at $4^{\circ} \mathrm{C}$. The samples were then rinsed in PBS and post-fixed with $1 \%$ osmium tetroxide for $45 \mathrm{~min}$ at room temperature. After dehydration in a graded series of ethanol solutions, the samples were cleared in propylene oxide and embedded in epoxy resin. Ultrathin sections were stained with lead citrate and examined under Hitachi H-500 or Philip CM-120 electron microscopy.

Flow cytometry (FCM). For the quantitative analysis of apoptosis and necrosis after HT, NTCT and HTCT, the annexin V-FITC and PI double staining method detected by FCM were used in this study on AGS and SNU-1. The procedures were based on the Annexin V-FITC apoptosis detection kit (BD Biosciences, USA). Briefly, cells were 
Table II. Primers used for QRT-PCR analysis.

\begin{tabular}{|c|c|c|c|}
\hline Gene & & Sequence (5' to $\left.3^{\prime}\right)$ & Product size (bp) \\
\hline TNF & $\begin{array}{l}\text { Forward } \\
\text { Reverse }\end{array}$ & $\begin{array}{l}\text { CGAGTCTGGGCAGGTCTACTTT } \\
\text { GGAGGCGTTTGGGAAGGT }\end{array}$ & 74 \\
\hline DR3 & $\begin{array}{l}\text { Forward } \\
\text { Reverse }\end{array}$ & $\begin{array}{l}\text { CTGTAAGCCAGGCTGGTTTGT } \\
\text { TAGGCATGGTTGGCAGTAGAAG }\end{array}$ & 79 \\
\hline BLK & $\begin{array}{l}\text { Forward } \\
\text { Reverse }\end{array}$ & $\begin{array}{l}\text { CCCAAGCCCTCTCCATGAG } \\
\text { GGCAGAGTTAGCAAACCTCCAT }\end{array}$ & 91 \\
\hline BNIP3 & $\begin{array}{l}\text { Forward } \\
\text { Reverse }\end{array}$ & $\begin{array}{l}\text { ACAGCTCACAGTCTGAGGAAGATG } \\
\text { CGACTTGACCAATCCCATATCC }\end{array}$ & 97 \\
\hline CIDE-B & $\begin{array}{l}\text { Forward } \\
\text { Reverse }\end{array}$ & $\begin{array}{l}\text { GGATTGTGTTCATTTTGAGGGTTT } \\
\text { TGCAGCCGTGATGGACAGT }\end{array}$ & 74 \\
\hline GAPDH & $\begin{array}{l}\text { Forward } \\
\text { Reverse }\end{array}$ & $\begin{array}{l}\text { GGACCTGACCTGCCGTCTAG } \\
\text { GTAGCCCAGGATGCCCTTGA }\end{array}$ & 100 \\
\hline
\end{tabular}

harvested $24 \mathrm{~h}$ after treatment, then collected cells were washed with cold PBS twice and stained with annexin V-FITC and PI. The samples were analyzed by FCM (FACSCalibur, $\mathrm{BD}, \mathrm{USA}$ ) within $1 \mathrm{~h}$.

cDNA microarray. For further understanding the mechanisms of apoptosis induction under HTCT, AGS cells $24 \mathrm{~h}$ after NT, HT, NTCT and HTCT (CDDP $1 \mu \mathrm{g} / \mathrm{ml}$ ) treatment were analyzed by a non-radioactive apoptosis gene array (Human Apoptosis GEArray Q series, HS-002, SuperArray Bioscience, USA) which included 96 key apoptosis-related genes (list of genes available at www.superarray.com). Briefly, total RNA was extracted from cell samples with the TRIzol reagent (Invitrogen, Life Technologies, USA). The quality of RNA was assessed by denaturing agarose gel electrophoresis. cDNA was prepared by reverse transcription reaction and hybridized to the arrays according to the manufacturer's instructions. The resulting hybridization signal was visualized by chemiluminescence and the digital image was converted to a raw data file using Scanalyze software (www.microarray.org/software.html). GEArray Analyzer software was used for data analysis, RNA levels were expressed as the relative A after normalizing the hybridization signals to the housekeeping gene GAPDH. A relative signal difference of $\geq 2$-fold in signal intensity was considered significant.

Quantitative real-time PCR ( $Q R T$ - $P C R)$. First-strand cDNA was synthesized from $1 \mu \mathrm{g}$ total RNA using the Reverse Transcription System (Promega, USA). QRT-PCR was performed on DNA engine Opticon II system (MJ Research, USA) using the SYBR-Green PCR Master Mix reagent (Applied Biosystems, USA) as a detector according to the manufacturer's instructions. Amplification were carried out with the following profile: 1 cycle at $50^{\circ} \mathrm{C}$ for $2 \mathrm{~min}, 1$ cycle at $95^{\circ} \mathrm{C}$ for $10 \mathrm{~min}$, and 40 cycles each at $95^{\circ} \mathrm{C}$ for $15 \mathrm{sec}$ and $59^{\circ} \mathrm{C}$ for $1 \mathrm{~min}$. To standardize the amount of RNA, the GAPDH gene was used as an endogenous control. The primers of the TNF, DR3, BLK, BNIP3, CIDE-B and GAPDH genes were designed using the Primer Express software (Applied Biosystems) and the sequences are shown in Table II.

Quantification results were expressed in terms of the cycle threshold $(\mathrm{Ct})$ value. The relative expression of each mRNA was calculated by the $\Delta \mathrm{Ct}$ method ( $\Delta \mathrm{Ct}$ is the value obtained by subtracting the $\mathrm{Ct}$ value of the GAPDH mRNA from the $\mathrm{Ct}$ value of the target mRNA). Therefore, the expression amount (power) of target relative to the GAPDH mRNA was expressed as $10,000 \times 2^{-(\Delta \mathrm{Ct})}$. Studies were conducted in triplicate and data are shown in mean value.

\section{Results}

MTT. The impact of HT on cell proliferation was different for various gastric cancer cell lines. As shown in Fig. 1, the impact of HT on the proliferation of adherent gastric cancer cell lines was limited: 24-72 $\mathrm{h}$ after HT, the A values were lower than those of NT. However, the ratios were close to 1 or even above 1 at $120 \mathrm{~h}$ after HT. SNU-1 was thermosensitive: the A ratios between HT and NT were always below 0.5. While SNU-16 was thermotolerant, the growth curves of NT and HT overlapped.

Growth curves were compared after treatment with different CDDP concentration and temperature combinations. Similar results were achieved for different cell lines, except for the differences in CDDP concentration and temperature combinations to inhibit proliferation due to the diverse chemosensitivity and thermosensitivity of various cell lines. Here we take AGS as an example (Fig. 2) and summarize the data of other cell lines in Table III. On the whole: i) The susceptibility of various cell lines to CDDP was diverse. AGS was relatively resistant, cell proliferation could only be inhibited when CDDP concentration was $16 \mu \mathrm{g} / \mathrm{ml}$ or higher. While SNU-1 was relatively sensitive, CDDP at concentration of $2 \mu \mathrm{g} / \mathrm{ml}$ is enough to inhibit cell proliferation. The concentration inhibiting most cell growth of MKN45, SGC7901, N87 and SNU-16 were $8 \mu \mathrm{g} / \mathrm{ml}, 4 \mu \mathrm{g} / \mathrm{ml}, 4 \mu \mathrm{g} / \mathrm{ml}$ and $4 \mu \mathrm{g} / \mathrm{ml}$, respectively. ii) The cytotoxicity and proliferation inhibition of CDDP was dose-dependent in certain dose ranges. iii) Combining with HT enhanced the 

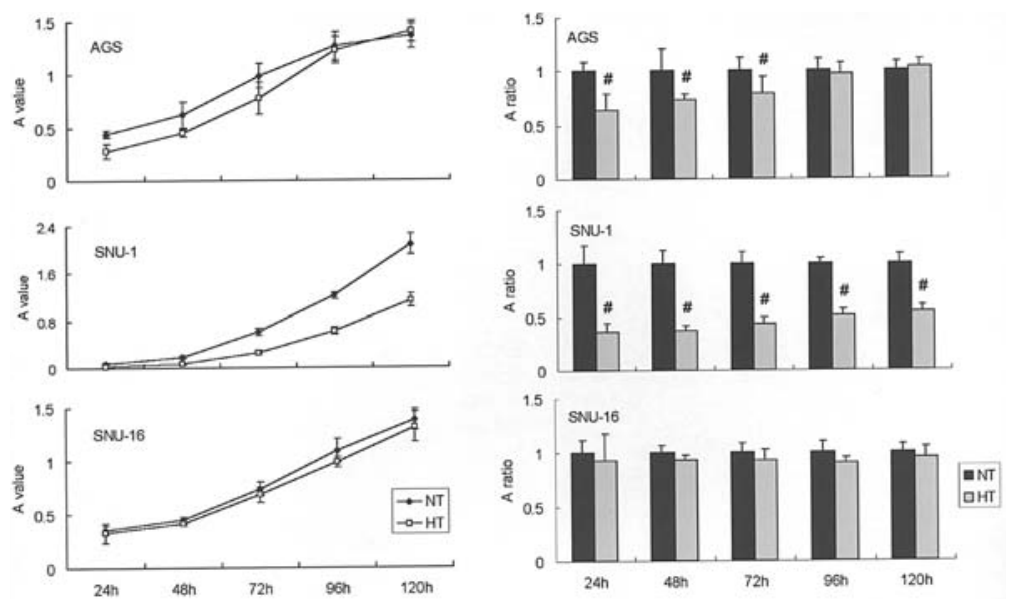

Figure 1. The impact of HT on cell proliferation for different stomach cancer cell lines. Growth curves are on the left, A ratios between NT and HT are on the right. The impact of isolated HT on adherent cell lines was similar, therefore, we only take AGS as an example. The above figures for each cell line are a representative result among 3-4 independent experiments. ${ }^{*} \mathrm{P}<0.05$ and ${ }^{\#} \mathrm{P}<0.01$, significant difference between NT and HT by the t-test.
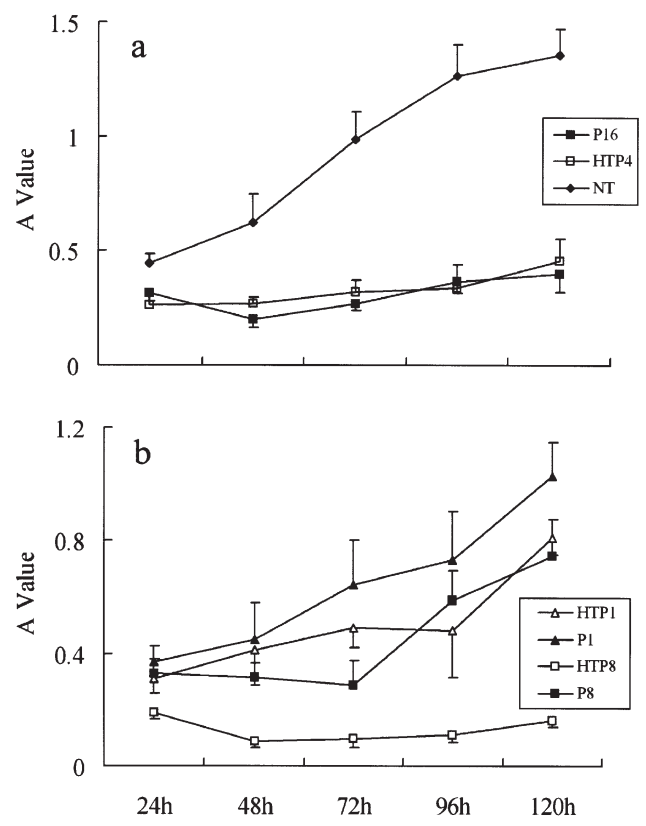

Figure 2. Comparison of growth curves after treatment with different CDDP concentrations and temperature combination for AGS cell. (a) The threshold concentration of CDDP inhibiting most of AGS cells growth ${ }^{\mathrm{a}}$ under NTCT and HTCT is different. Under NTCT, the threshold concentration was $16 \mu \mathrm{g} / \mathrm{ml}$. Under HTCT, the concentration was $4 \mu \mathrm{g} / \mathrm{ml}$. (b) The cytotoxicity of CDDP on AGS was enhanced when combined with HT. The figure shows a great difference between HTCT and NTCT with the same CDDP

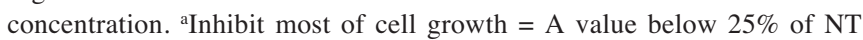
control. $\mathrm{P}=$ chemotherapy with CDDP in normothermia, the figure following represents concentrations of CDDP, e.g. P1 means chemotherapy with CDDP of $1 \mu \mathrm{g} / \mathrm{ml}$; HTP = hyperthermic chemotherapy with CDDP. Each CDDP concentration and temperature combination had one growth curve. Only some representative curve lines were picked out and others were omitted for a clear sight and better understand. The above curves were one representative result among 3-4 independent experiments.

cytotoxicity of CDDP in all gastric cell lines, particularly in a low concentration. The concentrations, which inhibited the cell proliferation of HTCT were much lower than those of NTCT.

We also studied the synergistic effect of hyperthermia and chemotherapy on inhibiting proliferation of various cell
Table III. Comparison of CDDP concentrations in inhibiting cell proliferation between NTCT and HTCT $(\mu \mathrm{g} / \mathrm{ml})$.

CDDP concentration inhibiting most of cell growth

\section{$\operatorname{NTCT}(\geq)$}

$\operatorname{HTCT}(\geq)$

\begin{tabular}{lll}
\hline AGS & 16 & 4 \\
MKN45 & 8 & 2 \\
SGC7901 & 4 & 1 \\
N87 & 4 & 2 \\
SNU-1 & 2 & 0.5 \\
SNU-16 & 4 & 1 \\
\hline
\end{tabular}

Inhibit most of cell growth=A value below $25 \%$ of NT control.

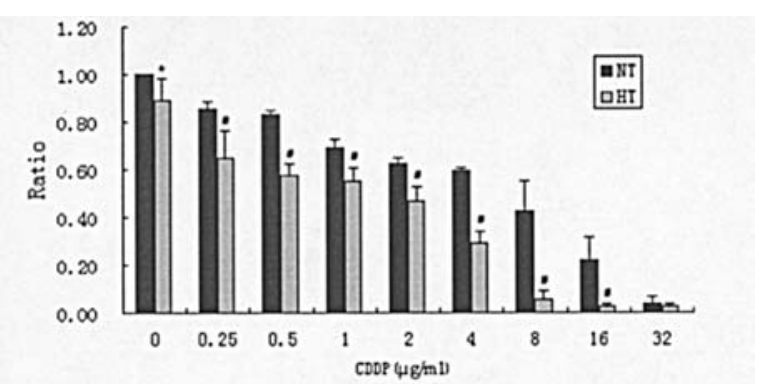

Figure 3. The synergistic effect of hyperthermia and chemotherapy on inhibiting proliferation in AGS cells. The cytotoxicity of CDDP on AGS was dose-dependent. HT and chemotherapy both inhibited AGS cell proliferation at $72 \mathrm{~h}$ after treatment, $\mathrm{P}<0.001$. Factorial analysis showed a synergistic effect of HT and chemotherapy, $P=0.0163$. There were significant differences between NTCT and HTCT with a CDDP concentration range from 0 to $16 \mu \mathrm{g} / \mathrm{ml} .{ }^{*} \mathrm{P}<0.05$; ${ }^{\#} \mathrm{P}<0.01$.

lines. The synergistic effect of hyperthermia and chemotherapy on inhibiting proliferation was observed in each gastric cell line in a certain range of CDDP concentration. Here we take AGS as an example (Fig. 3) and summarize the data of other cell lines in Table IV. 
Table IV. Synergistic effect of HT and chemotherapy.

\begin{tabular}{lcc}
\hline Cell line & Synergistic effect ${ }^{\mathrm{a}}$ & $\begin{array}{c}\text { CDDP concentration range with significant } \\
\text { differences between NTCT and HTCT }\end{array}$ \\
\hline AGS & $\mathrm{P}=0.0163$ & $0-16 \mu \mathrm{g} / \mathrm{ml}$ \\
MKN45 & $\mathrm{P}<0.001$ & $0-32 \mu \mathrm{g} / \mathrm{ml}$ \\
SGC7901 & $\mathrm{P}<0.001$ & $0-8 \mu \mathrm{g} / \mathrm{ml}$ \\
N87 & $\mathrm{P}<0.001$ & $0-8 \mu \mathrm{g} / \mathrm{ml}$ \\
SNU-1 & $\mathrm{P}<0.001$ & $0-8 \mu \mathrm{g} / \mathrm{ml}$ \\
SNU-16 & $\mathrm{P}<0.001$ & $0-4 \mu \mathrm{g} / \mathrm{ml}$ \\
\hline
\end{tabular}

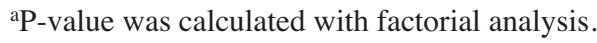

Observation of morphological changes after HT, NTCT and HTCT by light microscopy. For adherent cell lines, the morphological changes after treatment were similar. The differences were in CDDP concentrations and time intervals to produce similar morphological changes due to diverse chemosensitivity of various cell lines. Here we take AGS as an example (Fig. 4). In summary: i) Isolated HT produced some round detached cells and inhibited cell proliferation for a short period after treatment. However, at the end of our observation period, the cell density seemed close to NT control. ii) NTCT and HTCT both resulted in cell death in a certain range of CDDP concentration, but the threshold was totally different. Under NTCT, $4 \mu \mathrm{g} / \mathrm{ml}$ was the lowest CDDP concentrations inducing AGS cell death. Under HTCT, the threshold concentration inducing cell death was $1 \mu \mathrm{g} / \mathrm{ml}$, much lower than that of NTCT.

In suspension cell lines, the response of SNU-16 to HT, NTCT and HTCT was similar to that of adherent cell line except for its suspension growth pattern. SNU-1 was an exception; isolated HT induced cell death.

TEM showed that HTCT induced AGS and SNU-1 cell death, including apoptosis and necrosis. For AGS cell (Fig. 5), isolated HT did not induce cell death. Cells seemed similar to the untreated cells at $24 \mathrm{~h}$ after HT treatment, and to lowdose NTCT (CDDP $1 \mu \mathrm{g} / \mathrm{ml}$ ). At this concentration, HTCT induced cell death, including apoptosis and necrosis. At a relatively high dose (CDDP $4 \mu \mathrm{g} / \mathrm{ml}$ ), necrosis and apoptosis were observed under NTCT and HTCT, but HTCT killed more cells than NTCT.

For SNU-1 cells (Fig. 6), under NTCT, there was no significant ultrastructure change and cell death at low dose (CDDP $1 \mu / \mathrm{ml}$ ). At a relatively high dose (CDDP $4 \mu \mathrm{g} / \mathrm{ml}$ ), NTCT induced cell death, including apoptosis and necrosis. Unlike AGS, isolated HT killed SNU-1 cells. With the raising of CDDP concentrations, cell death was more extensive under HTCT.

Quantitative analysis of apoptosis and necrosis after HT, NTCT and HTCT on AGS and SNU-1 by FCM detection. Data are summarized in Fig. 7. As shown in Fig. 7b, the cytotoxicity of CDDP on AGS was dose-dependent. When the CDDP concentration was above $8 \mu \mathrm{g} / \mathrm{ml}$, less than $27.4 \%$ of cells were viable. The death-rate did not increase when the
CDDP concentration was below $0.5 \mu \mathrm{g} / \mathrm{ml}$. Between 1 $\mu \mathrm{g} / \mathrm{ml}$ and $2 \mu \mathrm{g} / \mathrm{ml}$, NTCT did not, while HTCT did increase cell death rate. Apoptosis was the major type of cell death under HTCT because more than $50 \%$ of cell death occurred in early apoptosis. The threshold of CDDP in inducing apoptosis under HTCT was $1 \mu \mathrm{g} / \mathrm{ml}$, much lower than that of NTCT $(4 \mu \mathrm{g} / \mathrm{ml})$. At a concentration of $4 \mu \mathrm{g} / \mathrm{ml}$, the difference of the cell death-rate between NTCT and HTCT was the greatest.

For SNU-1 (Fig. 7c), under NTCT, low-dose CDDP ( $2 \mu \mathrm{g} / \mathrm{ml}$ and $4 \mu \mathrm{g} / \mathrm{ml}$ ) only slightly increased the death rates. Isolated HT induced cell death, including apoptosis and necrosis. Combining with HT remarkably increased the celldeath rate and there was a synergistic effect of HT and chemotherapy on inducing cell death $(\mathrm{P}<0.0001)$. The proportion of early apoptosis in the dead cells was $\sim 45 \%$ (42.5\%-49.8\%), slightly lower than that of AGS.

Microarray identified some apoptosis genes which changed significantly under HTCT treatment. Compared with untreated cells (NT), 38 apoptosis-related genes had significant expression change when AGS cells were treated of with isolated HT. Treatment with NTCT (CDDP $1 \mu \mathrm{g} / \mathrm{ml})$ resulted in significant change in 46 genes. Under HTCT, a total of 58 gene expressions were regulated according to filtering criteria, including 10 genes with an expression change below the threshold or even unchanged under treatment with either HT or CDDP alone (Table IV). Nine were up-regulated and 1 was down-regulated, all belonging to diverse functional genes involved in apoptosis. Most up-regulated genes are apoptosis-promotors, except FLIP, which is an inhibitor of the Fas-associated apoptosis pathway (Table V). Five of them were validated by QRT-PCR, and the expression changes of 4 genes were identical to those of microarray (Fig. 8).

The gene expressions of all five members of death domain family (CRADD, DAPK2, FADD, MYD88, RIPK1) were up-regulated (Fig. 9). Four of them accorded with the filtering criteria, DAPK2 was the exception.

\section{Discussion}

Many studies in vitro have proved that isolated HT for 1 to $3 \mathrm{~h}$ kills tumor cells from various origins, such as retinoblastoma 
A

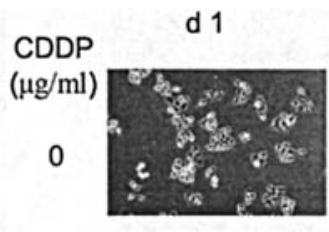

0.5

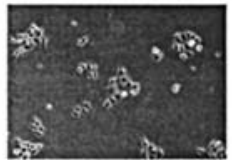

1

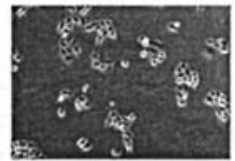

2

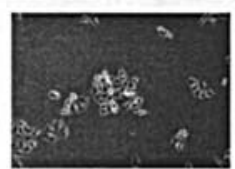

4

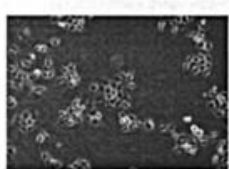

8

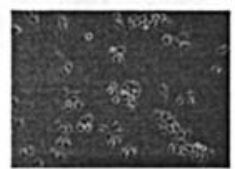

d 1

CDDP

$(\mu \mathrm{g} / \mathrm{ml})$

0

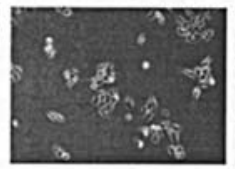

0.5

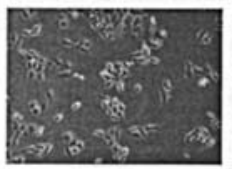

1
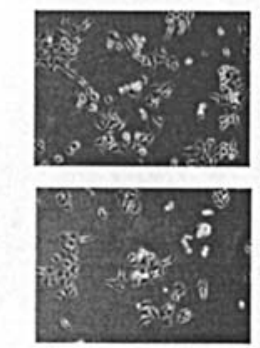

4

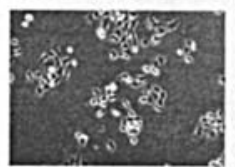

8

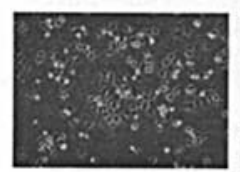

d 2
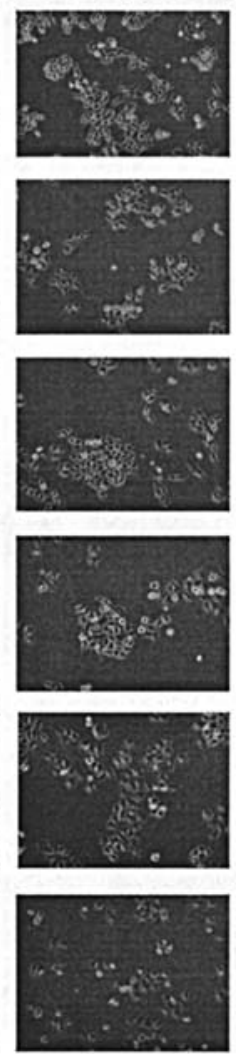

d 2
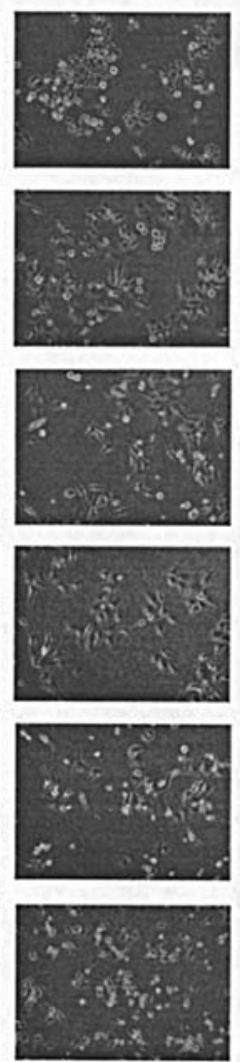

d 3
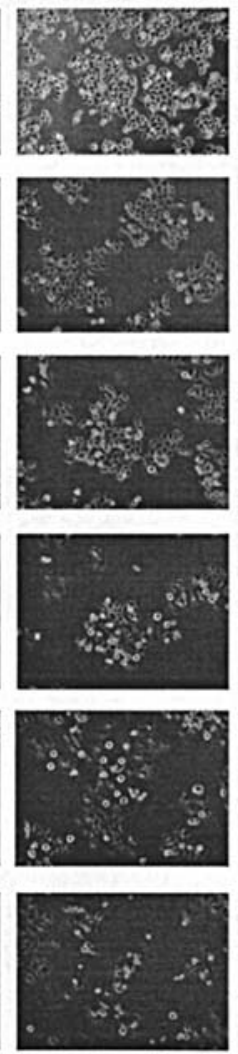

d 3
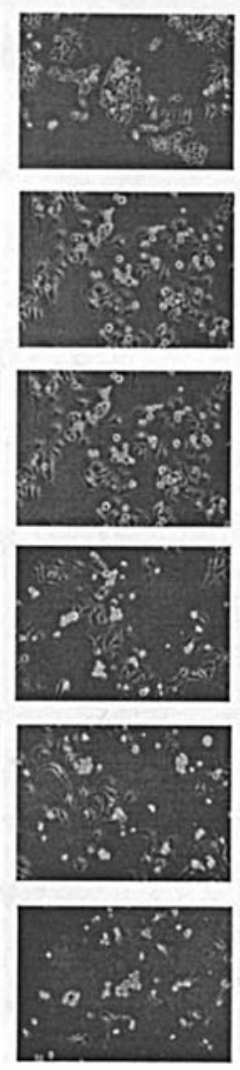

d 4
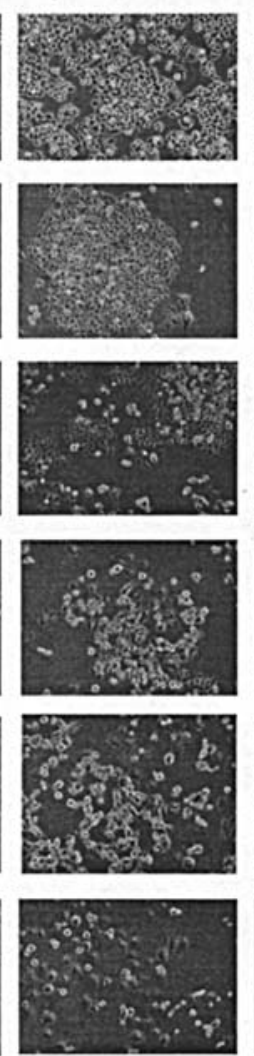

d 4
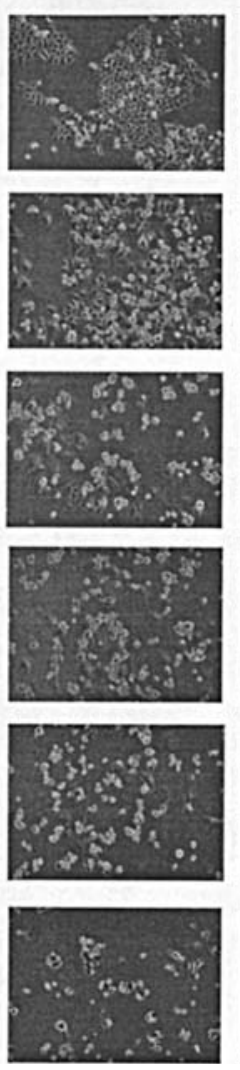

d 5
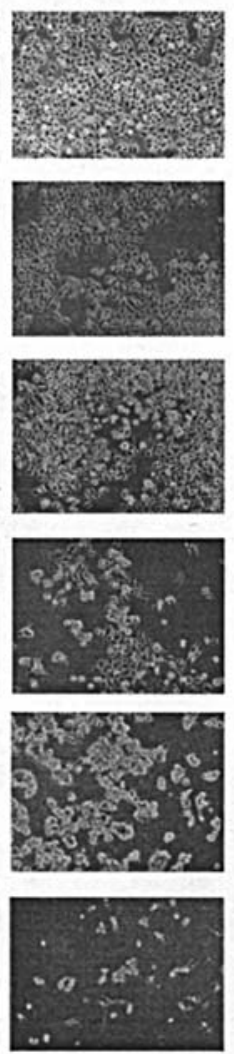

d 5
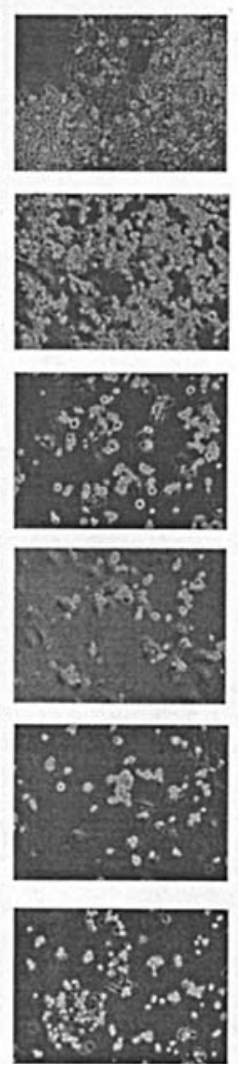

Figure 4. Morphological changes of AGS after NTCT and HTCT under light microscopy. (a and b) showed morphological changes of AGS cell after NTCT and HTCT, respectively. Under NT conditions: There were no significant morphological changes when CDDP concentrations were below $1 \mu \mathrm{g} / \mathrm{ml}$, and cells proliferated normally. At $2 \mu \mathrm{g} / \mathrm{ml}$, there were some round detached cells and the cell density was lower than that of NT control. At $4 \mu \mathrm{g} / \mathrm{ml}$, some dead cells could be observed at $72 \mathrm{~h}$ after treatment and the cell density was much lower. At $8 \mu \mathrm{g} / \mathrm{ml}$, cell death was more extensive and there were few viable cells at $120 \mathrm{~h}$ after treatment. Under HT condition: Isolated HT only produced some round detached cells. There was no significant growth inhibition at the end of the observation period. A number of dead cells were observed when the CDDP concentration was $1 \mu \mathrm{g} / \mathrm{ml}$. Above $4 \mu \mathrm{g} / \mathrm{ml}$, cell death was prevalent and few cells survived at $96 \mathrm{~h}$ after treatment. Magnification x100. 

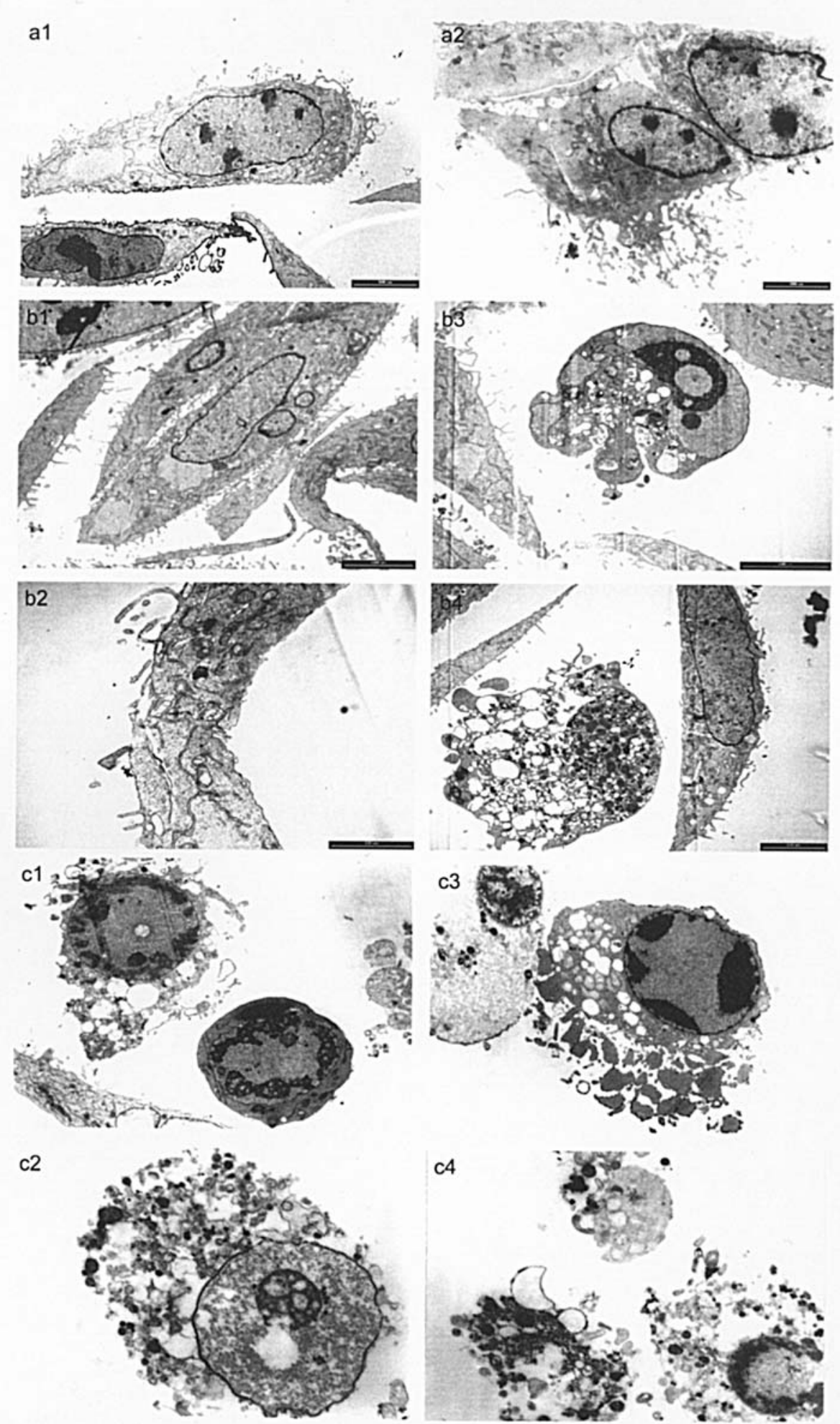

Figure 5. Morphological changes of AGS after HT, CT and HTCT under TEM. (a) Comparison between the NT control and HT treatment. (a1) Normal untreated cells. The cells had abundant microvilli and organelles. Nuclei were round or ovoid containing one or more nucleoli. (a2) There was no significant ultrastructure change when cells were treated with HT only. (Magnification x4200). (b) Comparison between NTCT (b1 and b2) and HTCT (b3 and b4) when the CDDP concentration was $1 \mu \mathrm{g} / \mathrm{ml}$. There was no significant morphological change under NTCT (b1). Fine intercellular bridges were observed between two cells (b2). Under HTCT, a few apoptotic cells with condensed chromatin (b3) and necrotic cells (b4) were observed. (Magnification: b1, x4200; b2, $\mathrm{x} 135000 ; \mathrm{b} 3, \mathrm{x} 5800 ; \mathrm{b} 4, \mathrm{x} 4200$ ). (c) Comparison between NTCT (c1 and c2) and HTCT (c3 and c4) when the CDDP concentration was $4 \mu \mathrm{g} / \mathrm{ml}$. Some small apoptotic cells (c1) and large necrotic cells (c2) were observed under NTCT. HTCT induced more cell death, including apoptosis (c3) and necrosis (c4). (Magnification: c1, x6000; c2, x8000; c3, x8000; c4, x 7000).

(9), osteosarcoma (10-11), glioblastoma (12), melanoma $(13,14)$ and histiocytoma $(15)$. As for gastric cancer cells, only few reports were found in Medline database (16-18), and the temperature and cell lines used were inconsistent or the treatment conditions were not similar as those of IPHC. Therefore, we selected six frequently used cell lines of 


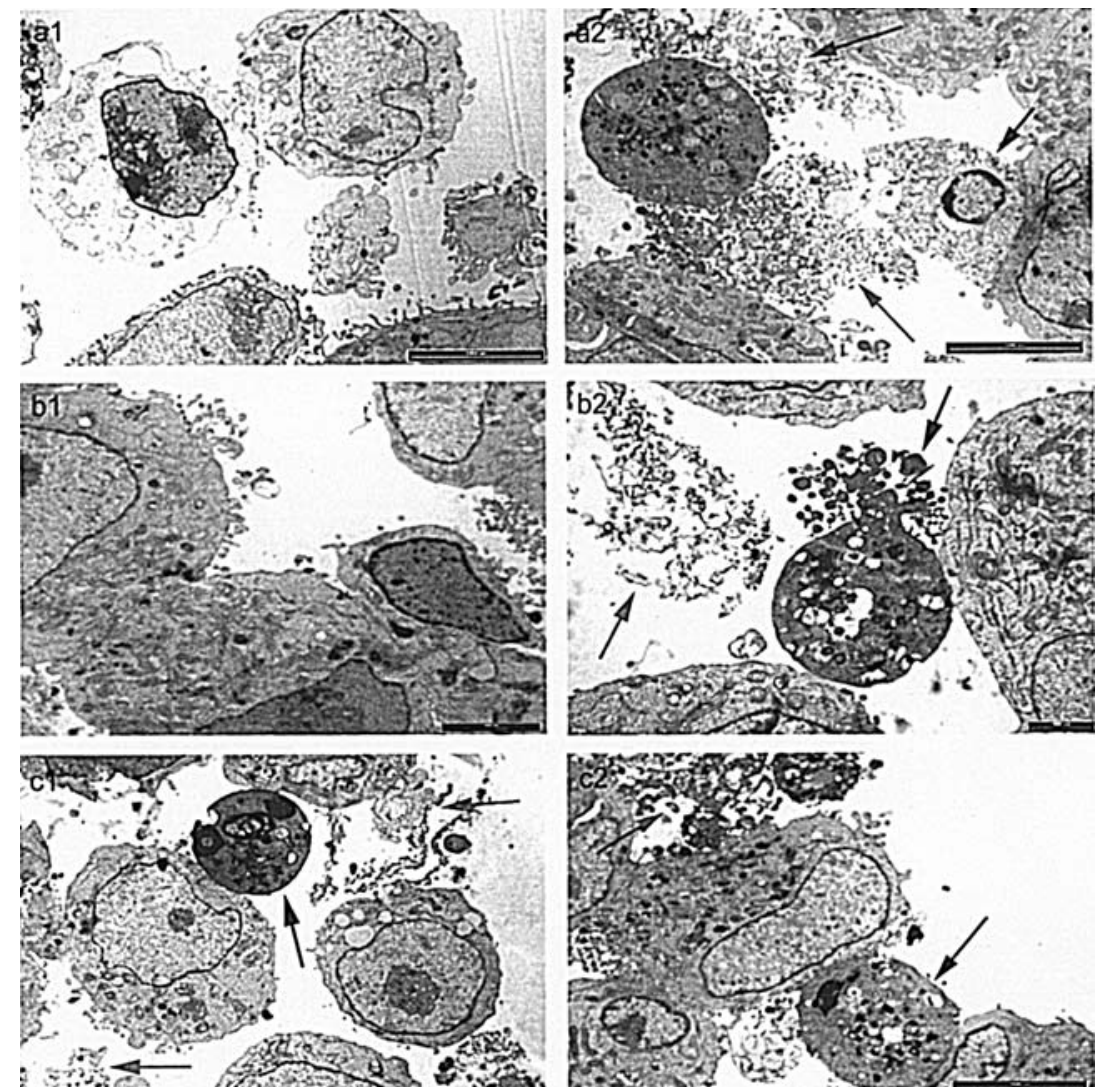

Figure 6. Morphological changes of SNU-1 after HT, CT and HTCT under TEM. (a1) Normal untreated cells. They were round or ovoid with abundant organelles and one or more nucleoli. Isolated HT induced cell death; an apoptotic cell with crescent-like chromatin condensation (black arrow) and two collapsed necrotic cells (gray arrow) were observed (a2). There was no significant morphological change when cells were treated with $1 \mu \mathrm{g} / \mathrm{ml} \mathrm{CDDP} \mathrm{under}$ NTCT (b1). Under HTCT (CDDP $1 \mu \mathrm{g} / \mathrm{ml}$ ), cell death was more extensive, TEM showed an apoptotic cell characterized with apoptotic bodies (dark arrow) and a collapsed cell (gray arrow) in (b2). Apoptosis (dark arrow) and necrosis (gray arrow) were observed when the CDDP concentration was $4 \mu \mathrm{g} / \mathrm{ml}$ both under NTCT (c1) and HTCT (c2). (Magnification: a1, x3400; a2, x3400; b1, x4200; b2, x5800; c1, x4200; c2, x3400).
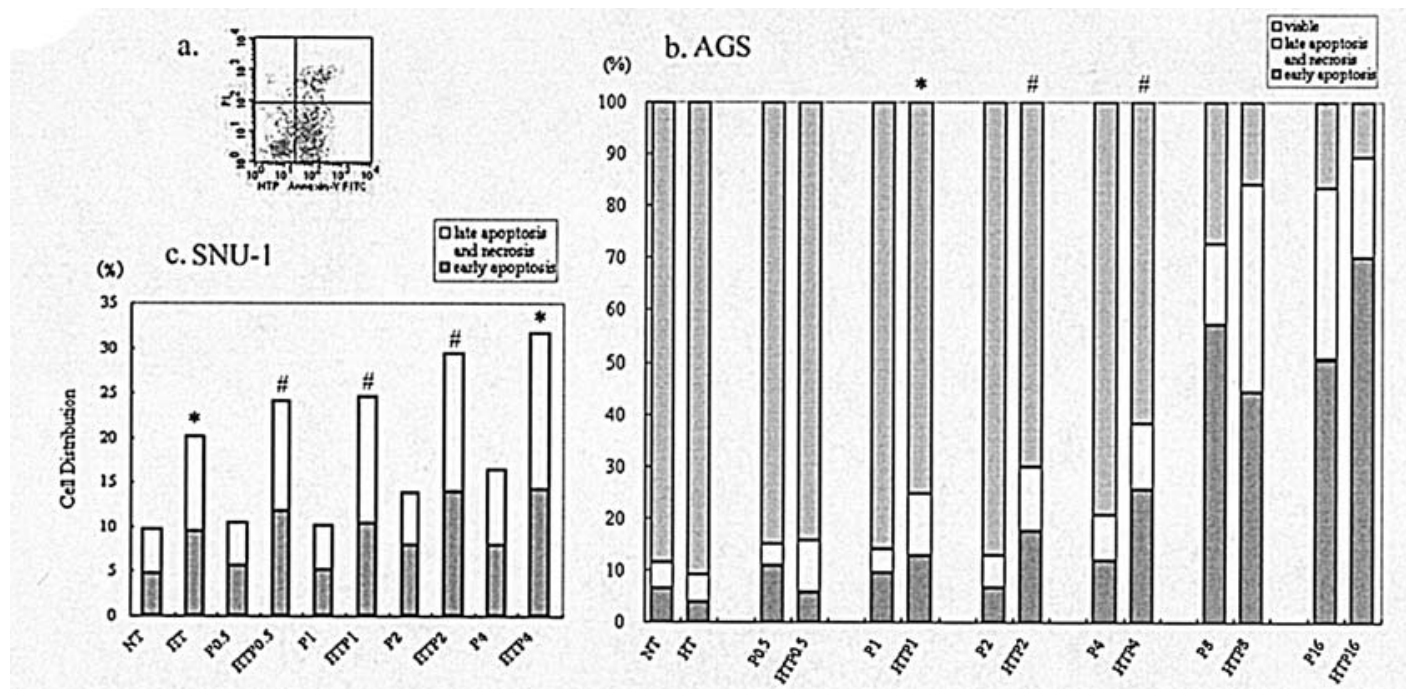

Figure 7. Quantitative analysis of apoptosis and necrosis after HT, NTCT and HTCT on AGS and SNU-1 by FCM detection. Data are presented as dot plots analyzed by FCM. Annexin V- and PI-negative dots are regarded as 'viable' cells; others are 'dead' cells. Annexin V-positive and PI-negative dots represent early apoptotic cells and PI-positive dots represent late apoptotic and necrotic cells (a). The percentages of viable, apoptotic and necrotic cells were determined by counting cells in each of the quadrants of the FCM dot plot, then, the data were transferred and summarized (b and c). The values are the means of three experiments. Significant difference of the percentage of 'dead' cells in total between NT and HT, NTCT and HTCT is expressed as "P $<0.05$ and ${ }^{~} \mathrm{P}<0.01$ determined by the $\mathrm{t}$-test.

different origins, differentiation and growth properties, in order to comprehensively understand the impact of hyperthermia on gastric cancer cells. We also simulated the temperature and duration of IPHC in vitro and made observations for a relatively long period (up to $120 \mathrm{~h}$ after HT treatment). Surprisingly, in our experimental modality, isolated HT had a cell-killing effect only on the SNU-1 cell line. For other cell lines, we only observed temporary 
Table V. Ten genes, which were clearly changed in expression levels when treated with HTCT but unchanged under either HT or CDDP alone.

\begin{tabular}{lll}
\hline Category & Gene & \\
\hline TNF ligand family & TNF & Ligand of TNFR1, proapoptotic \\
TNF receptor family & DR3 & Death receptor, proapoptotic \\
& HVEM & Proapoptotic \\
Bcl-2 family & BLK & Both promote mitochondria associated \\
& BNIP3 & apoptosis, proapoptotic \\
Caspase family & CASP5 & Apoptosis-related cysteine protease, proapoptotic \\
& CASP10 & Apoptosis-related cysteine protease, proapoptotic \\
CARD family & HuE10 & Proapoptotic \\
Death effector domain family & FLIP & Inhibitor of Fas-related apoptosis, antiapoptotic \\
CIDE domain family & CIDEB & Induce DNA fragment, proapoptotic
\end{tabular}

${ }^{a}$ The only down-regulated gene, the others were all up-regulated.

inhibition of proliferation. Compared with some other malignancies, gastric cancer cells are relatively thermotolerant and cell-killing by short-time hyperthermia is not prevalent. The difference may be that cell lines established from different tumors have diverse thermosensitivity.

Similar to the results of many other studies $(9,19-22)$, MTT assay and FCM detection in this study proved that there was a synergistic effect of HT and chemotherapy. Although the susceptibility of CDDP to each cell line was different, the phenomenon of the synergistic effect existed in all 6 gastric cancer cell lines. For each cell line, HTCT had a stronger cell-killing effect than NTCT in a certain dose range, and HTCT induced cell death when treated with a lower concentration of CDDP at which NTCT was not enough to kill cancer cells. This is clinically important because gastric cancer may be resistant to a single stimulus of HT or certain concentration of anticancer drug and, therefore, the combination may be effective by reducing the dose of anticancer drug to avoid side effects. In addition, we investigated the relationship between the synergistic effect of cytotoxicity and the cell line's origin, differentiation and growth property, but no definite rule was found except that two suspension cell lines were more sensitive to CDDP than four adherent ones.

There are two modes of cell death, necrosis and apoptosis. Most previous reports of morphological studies of cell death induced by chemotherapy and thermotherapy have referred only to 'necrosis' (23). Several studies have shown that apoptosis is the major mode of cell death induced by hyperthermia and anti-cancer drugs such as CDDP $(4,9,20,24-26)$. In our study, TEM proved that HT, chemotherapy and HTCT killed cancer cells by inducing both apoptosis and necrosis. We used FCM to quantitatively analyze the proportion of apoptosis and necrosis. For SNU-1, the only cells in our study which were killed by HT, $47.8 \%$ of dead cells were recognized in the early stage of apoptosis, others in the late stage of apoptosis and necrosis. When combined with chemotherapy, the proportion of early apoptosis in cell death was $\sim 45 \%$. For AGS, $>50 \%$ of cell death belonged to early apoptosis under HTCT when the CDDP concentration was above $1 \mu \mathrm{g} / \mathrm{ml}$. Therefore, apoptosis play a predominant role in cell-killing by HTCT. We conclude that inducing apoptosis is the major mechanism of killing AGS cell under HTCT.

Based on the results of FCM and morphological observation, the threshold of HTCT in inducing apoptosis of AGS cell was $1 \mu \mathrm{g} / \mathrm{ml}$, at which NTCT had no significant impact on the cells. When the CDDP concentration was 4 $\mu \mathrm{g} / \mathrm{ml}$, the difference between NTCT and HTCT in inducing cell death was the greatest. Therefore, these concentrations should be used to further explore the detailed mechanism of how HTCT induces AGS cell apoptosis.

The mechanisms of the synergistic effect between HT and chemotherapy and how HTCT induces apoptosis of cancer cells are unclear because apoptosis and its regulations are complex. Recent advances in microarray technology provide an attractive new tool to analyze the genome transcriptional difference (27). However, some shortcomings in DNA chip technology such as low data reproducibility and difficulty in data analysis have to be overcome for better application to genomics study (28-30). However, small focused array, designed to determine the expression of genes involved in a specific biological pathway, or genes with similar functions or structural features, has been introduced. Compared with whole genome microarray, it is relatively sensitive, accurate and reliable, data handling is easier and more straightforward $(31,32)$. Because the mechanism of the cell-killing effect of HTCT is to induce apoptosis, a focused gene array was adopted to analyze the expression changes of apoptosisassociated genes after HT, NTCT and HTCT treatment in 

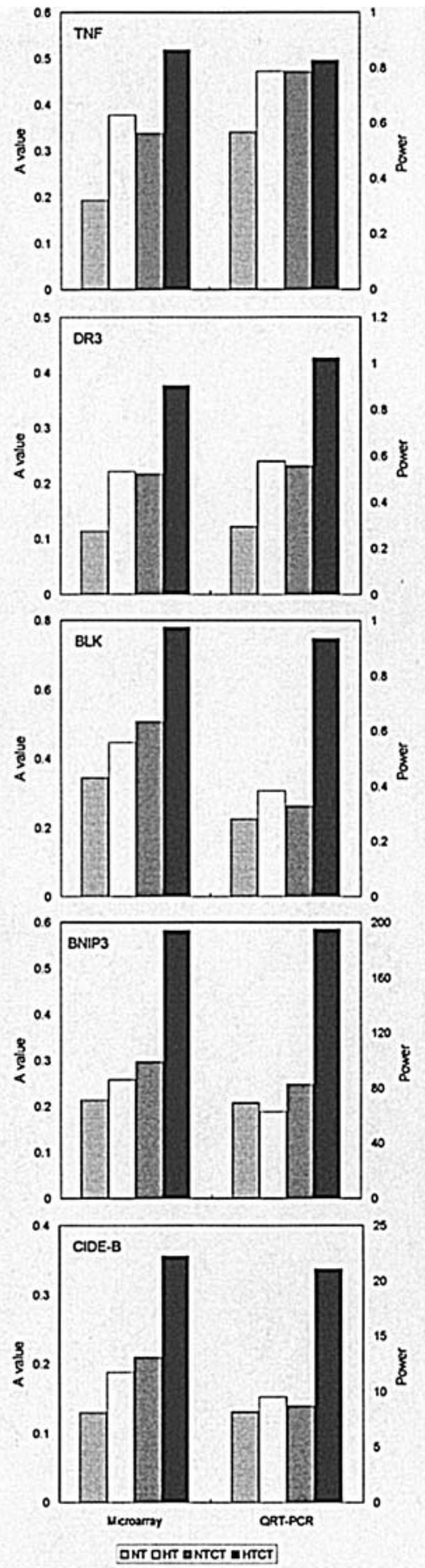

Figure 8. QRT-PCR validated the expression changes of five selected apoptosis genes identified from microarray. mRNA levels of five apoptosis related genes identified from microarray, including TNF, DR3, BLK, BNIP3 and CIDE-B, were validated by using QRT-PCR. The gene expressions tested by microarray and QRT-PCR under NT, HT, NTCT and HTCT are both described. The expression changes of 4 genes were consistent between the two methods. The result of TNF tested by QRT-PCR suggested the same trend when compared with that by microarray, but it did not reach the filtering criteria of ' $\geq 2$-fold in signal intensity' in microarray.

this study. The CDDP concentration used is $1 \mu \mathrm{g} / \mathrm{ml}$ due to the above reason. Differences in apoptosis gene expression profiles in response to HT, CDDP or combined treatment could be detected by this focused array. More gene expression changes were observed under HTCT than those

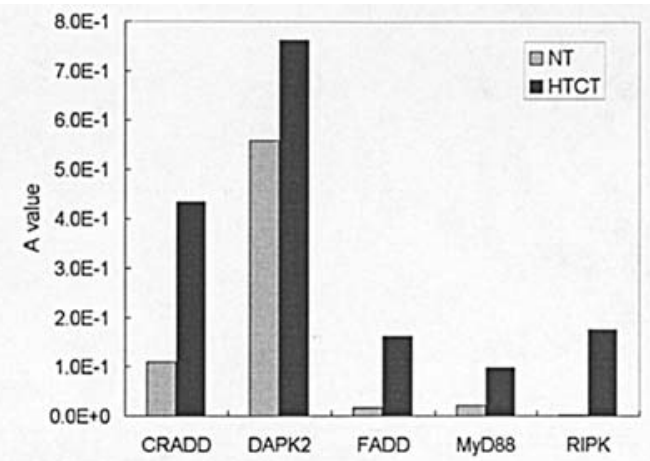

Figure 9. Gene expression changes of the Death Domain Family between NT and HTCT.

under HT or CDDP alone. Among them, ten genes with an expression change below the threshold or even unchanged under treatment with either HT or CDDP alone were identified. Together with members of the death domain family, these interesting genes may include the target genes for the enhancing effect of HT on chemotherapy and their effects should be further validated by functional analysis.

\section{Acknowledgements}

This study was supported by the Science and Technology Committee Foundation of Shanghai, No. 044119625.

\section{References}

1. Falk MH and Issels RD: Hyperthermia in oncology. Int J Hyperthermia 17: 1-18, 2001.

2. Wust P, Hildebrandt B, Sreenivasa G, Rau B, Gellermann J, Riess H, Felix R and Schlag PM: Hyperthermia in combined treatment of cancer. Lancet Oncol 3: 487-497, 2002.

3. Hildebrandt B, Wust P, Ahlers O, Dieing A, Sreenivasa G, Kerner T, Felix R and Riess H: The cellular and molecular basis of hyperthermia. Crit Rev Oncol Hematol 43: 33-56, 2002.

4. Dahl O, Dalene R, Schem BC and Mella O: Status of clinical hyperthermia. Acta Oncol 38: 863-873, 1999.

5. Fujimoto S, Takahashi M, Mutou T, Kobayashi K and Toyosawa T: Successful intraperitoneal hyperthermic chemoperfusion for the prevention of postoperative peritoneal recurrence in patients with advanced gastric carcinoma. Cancer 85: 529-534, 1999.

6. Hamazoe R, Maeta M and Kaibara N: Intraperitoneal thermochemotherapy for prevention of peritoneal recurrence of gastric cancer. Final results of a randomized controlled study. Cancer 73: 2048-2052, 1994.

7. Hirose K, Katayama K, Iida A, Yamaguchi A, Nakagawara G, Umeda $S$ and Kusaka Y: Efficacy of continuous hyperthermic peritoneal perfusion for the prophylaxis and treatment of peritoneal metastasis of advanced gastric cancer: evaluation by multivariate regression analysis. Oncology 57: 106-114, 1999.

8. Yonemura Y, de Aretxabala X, Fujimura T, Fushida S, Katayama K, Bandou E, Sugiyama K, Kawamura T, Kinoshita K, Endou Y and Sasaki T: Intraoperative chemohyperthermic peritoneal perfusion as an adjuvant to gastric cancer: final results of a randomized controlled study. Hepatogastroenterology 48: 1776-1782, 2001.

9. Choi EK, Park SR, Lee JH, Chung HS, Ahn HE, Rhee YH, Lim BU and Park HJ: Induction of apoptosis by carboplatin and hyperthermia alone or combined in WERI human retinoblastoma cells. Int J Hyperthermia 19: 431-443, 2003.

10. Wan SL, Zhang J, Yang DS and Fan SW: Cytotoxic effect of thermo-chemotherapy with cisplatin on osteosarcoma OS-732 cell line. Zhejiang Da Xue Xue Bao Yi Xue Ban 32: 427-432, 2003. 
11. Rong Y and Mack P: Apoptosis induced by hyperthermia in Dunn osteosarcoma cell line in vitro. Int J Hyperthermia 16: 19-27, 2000.

12. Fuse T, Yoon KW, Kato T and Yamada K: Heat-induced apoptosis in human glioblastoma cell line A172. Neurosurgery 42: 843-849, 1998.

13. Journee-de Korver HG, Midena E and Singh AD: Infrared thermotherapy: from laboratory to clinic. Ophthalmol Clin North Am 18: 99-110, viii-ix, 2005.

14. Han JS, Storck CW, Wachsberger PR, Leeper DB, Berd D, Wahl ML and Coss RA: Acute extracellular acidification increases nuclear associated protein levels in human melanoma cells during 42 degrees $C$ hyperthermia and enhances cell killing. Int J Hyperthermia 18: 404-415, 2002.

15. Yonezawa M, Otsuka T, Matsui N, Tsuji H, Kato KH, Moriyama A and Kato T: Hyperthermia induces apoptosis in malignant fibrous histiocytoma cells in vitro. Int $\mathrm{J}$ Cancer 66: 347-351, 1996.

16. Goto A, Shomori K, Ohkumo T, Tanaka F, Sato K and Ito H: Hyperthermia-induced apoptosis occurs both in a p53 genedependent and -independent manner in three human gastric carcinoma cell lines. Oncol Rep 6: 335-339, 1999.

17. Shchepotin IB, Shabahang M, Nauta RJ, Buras RR, Brenner RV and Evans SR: Antitumour activity of 5-fluorouracil, verapamil and hyperthermia against human gastric adenocarcinoma cells (AGS) in vitro. Surg Oncol 3: 287-294, 1994.

18. Buell JF, Reed E, Lee KB, Parker RJ, Venzon DJ, Amikura K, Arnold S, Fraker DL and Alexander HR: Synergistic effect and possible mechanisms of tumor necrosis factor and cisplatin cytotoxicity under moderate hyperthermia against gastric cancer cells. Ann Surg Oncol 4: 141-148, 1997.

19. Ehlers EM, Kuhnel W and Wiedemann GJ: Hyperthermia and mafosfamide in a human-derived malignant pleural mesothelioma cell line. J Cancer Res Clin Oncol 128: 65-72, 2002.

20. Ohtsubo T, Igawa H, Saito T, Matsumoto H, Park H, Song CW, Kano E and Saito H: Enhancement of cell killing by induction of apoptosis after treatment with mild hyperthermia at 42 degrees C and cisplatin. Radiat Res 156: 103-109, 2001.
21. Othman T, Goto S, Lee JB, Taimura A, Matsumoto T and Kosaka M: Hyperthermic enhancement of the apoptotic and antiproliferative activities of paclitaxel. Pharmacology 62: 208-212, 2001.

22. Nakao K, Otsuki Y, Akao Y, Ito Y, Marukawa O, Tachibana S, Kawakami M and Sasaki S: The synergistic effects of hyperthermia and anticancer drugs on induction of apoptosis. Med Electron Microsc 33: 44-50, 2000.

23. Fajardo LF, Egbert B, Marmor J and Hahn GM: Effects of hyperthermia in a malignant tumor. Cancer 45: 613-623, 1980.

24. Harmon BV, Takano YS, Winterford CM and Gobe GC: The role of apoptosis in the response of cells and tumours to mild hyperthermia. Int J Radiat Biol 59: 489-501, 1991.

25. Honma T: Characteristics of hyperthmia-induced apoptotic cell death. Nippon Rinsho 54: 1949-1954, 1996.

26. Conway RM, Madigan MC, Billson FA and Penfold PL: Vincristine- and cisplatin-induced apoptosis in human retinoblastoma. Potentiation by sodium butyrate. Eur J Cancer 34: 1741-1748, 1998.

27. Brentani RR, Carraro DM, Verjovski-Almeida S, Reis EM, Neves EJ, de Souza SJ, Carvalho AF, Brentani H and Reis LF: Gene expression arrays in cancer research: methods and applications. Crit Rev Oncol Hematol 54: 95-105, 2005.

28. Kothapalli R, Yoder SJ, Mane S and Loughran TP Jr: Microarray results: how accurate are they? BMC Bioinformatics 3: 22-31, 2002.

29. Luo Y, Cai J, Ginis I, Sun Y, Lee S, Yu SX, Hoke A and Rao M: Designing, testing, and validating a focused stem cell microarray for characterization of neural stem cells and progenitor cells. Stem Cells 21: 575-587, 2003.

30. Russo G, Zegar C and Giordano A: Advantages and limitations of microarray technology in human cancer. Oncogene 22: 6497-6507, 2003.

31. Luo Y, Cai J, Liu Y, Xue H, Chrest FJ, Wersto RP and Rao M: Microarray analysis of selected genes in neural stem and progenitor cells. J Neurochem 83: 1481-1497, 2002.

32. Draghici S, Khatri P, Shah A and Tainsky MA: Assessing the functional bias of commercial microarrays using the ontocompare database. Biotechniques 34 (Suppl): 55-61, 2003. 